8 


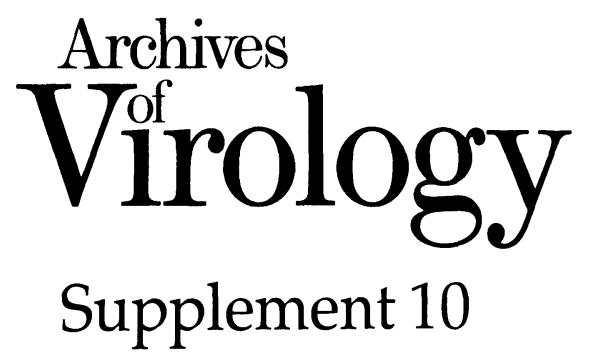




\author{
F.A. Murphy, C.M. Fauquet, D.H.L. Bishop, \\ S.A. Ghabrial, A.W. Jarvis, G.P. Martelli, M. A. Mayo, \\ M.D. Summers (eds.)
}

\title{
Virus Taxonomy
}

\section{Classification and Nomenclature of Viruses}

\author{
Sixth Report \\ of the International Committee \\ on Taxonomy of Viruses
}

Virology Division

International Union of Microbiological Societies 


\author{
Dr. Frederick A. Murphy \\ School of Veterinary Science, University of California, Davis, CA, U.S.A. \\ Dr. Claude M. Fauquet \\ ORSTOM/The Scripps Research Institute, La Jolla, CA, U.S.A. \\ Dr. David H. L. Bishop \\ Natural Environment Research School, Institute of Virology, Oxford, U.K.
Dr. Said A. Ghabrial
Department of Plant Pathology, University of Kentucky, Lexington, KY, U.S.A.
Dr. Audrey W. Jarvis \\ New Zealand Dairy Research Institute, Palmerston North, New Zealand \\ Dr. Giovanni P. Martelli \\ Instituto di Patologia Vegetale, Bari, Italy \\ Dr. Mike A. Mayo \\ Scottish Crop Research Institute, Dundee, U.K. \\ Dr. Max D. Summers \\ Department of Entomology, Texas A\&M University, College Station, TX, U.S.A.
}

This work is subject to copyright. All rights are reserved, whether the whole or part of the material is concerned, specifically those of translation, reprinting, re-use of illustrations, broadcasting, reproduction by photocopying machines or similar means, and storage in data banks.

\author{
(C) 1995 Springer-Verlag Wien \\ Originally published by Springer-Verlag/Wien in 1995 \\ Typesetting: Camera-ready by editors
}

Printed on acid-free and chlorine-free bleached paper

With 185 Figures

Cover illustration: The three-dimensional surface-shaded map of rotavirus by cryoelectron microscopy and image processing (diameter $\sim 1,000 \AA$ ). The surface is characterized by 60 VP4 haemagglutinin spikes that bind to cell surface receptors and mediate infection (front cover). Three protein shells encapsidate the dsRNA genome, which has been removed for clarity: an outer capsid shell formed by 780 VP7 molecules; an inner capsid shell formed by 260, pillarshaped, VP6 trimers; and a core shell formed primarily by VP2 as well as VP1 and VP3 (back cover) (with permission of Dr. M. Yeager, The Scripps Research Institute, La Jolla, California). From: The EMBO Journal, Volume 13, Number 7 (1 April 1994), front cover, by permission of Oxford University Press. 


\section{Preface And ACKNOWLedgments}

Virus taxonomy is a polarizing subject when it comes up in hallway conversations. Some virologists tune out immediately, others tune in. In the end, after the skeptics walk off, down the hallway, the intensity of the conversation usually increases, because if there is one truism about virus taxonomy it is that it brings out among virologists "strongly held opinions" (a euphemism for "polite arguments"). The point is that virus taxonomy is based upon opinion rather than data, or better, it is based upon the opinionated usage of data. Since one opinion is usually as valid as the next, chaos can reign, but starting in 1966, chaos started to give way to order as the International Committee on Nomenclature of Viruses, later changed to the International Committee on Taxonomy of Viruses (ICTV), set out to provide a single universal system for the classification and nomenclature of all viruses. The system has been based upon true international consensus building, and true pragmatism and it has been successful. The work of the Committee has been published in a series of reports, the Reports of the International Committee on Taxonomy of Viruses, The Classification and Nomenclature of Viruses. These Reports have become part of the history and infrastructure of modern virology:

\begin{tabular}{|c|c|c|}
\hline ICTV Report & Editors & $\begin{array}{l}\text { Reporting ICTV Proceedings at the } \\
\text { International Congresses } \\
\text { of Virology held in }\end{array}$ \\
\hline
\end{tabular}

The First Report, 1971

The Second Report, 1976

The Third Report, 1979

The Fourth Report, 1982

The Fifth Report, 1991
P. Wildy
F. Fenner
R. E. F. Mathews
R. E. F. Mathews
R. I. B. Francki, C. M. Fauquet,
D. L. Knudson, F. Brown

\author{
Helsinki, 1968 \\ Budapest, 1971 and Madrid, 1975 \\ The Hague, 1978 \\ Strasbourg, 1981 \\ Sendai, 1984, Edmonton, 1987 \\ and Berlin, 1990
}

This Report, the Sixth Report of the ICTV, adds to the accumulated taxonomic construction "in progress" since 1966. It records the proceedings of the Committee since 1990 and includes decisions reached at mid-term meetings in 1991 and 1992 and at the Ninth International Congress of Virology held in Glasgow in August of 1993.

The work of the Committee is far from complete - in fact, it would seem that as virus research continues to grow in breadth and depth and discoveries of the nature and diversity of the viruses become more and more amazing, the naïve goal of a "complete" taxonomy recedes into the distance. Virus taxonomy is a dynamic enterprise - to remain useful, it must continue to draw upon the wisdom and efforts of many virologists around the world, virologists representing all of the specialty disciplines that make up virology, overall. In this regard, this Report represents the work of about 400 virologists, the members of the Study Groups, Subcommittees and the Executive Committee of the ICTV for the term 19901993. The compilers of the Report wish to express their gratitude to all these virologists. We also wish to acknowledge, belatedly, the financial contribution of the Mayne Bequest Fund, the University of Queensland.

We also wish to express our gratitude to Ella Blanc, dedicated secretary to Dr. Claude M. Fauquet, and especially to Usha Padidam, responsible for the typing, formatting and layout of the VIth ICTV Report.

for the Committee

Frederick A. Murphy

President of the International Committee on Taxonomy of Viruses 


\title{
VIRUS TAXONOMY
}

\author{
Sixth Report \\ of the \\ International Committee on Taxonomy of Viruses
}

\section{Editors}

\author{
F.A. Murphy \\ School of Veterinary Medicine \\ University of California, Davis \\ Davis, CA 95616 \\ USA
}

\author{
C.M. Fauquet \\ ORSTOM/The Scripps Research Institute \\ Division of Plant Biology-MRC7 \\ 10666 North Torrey Pines Rd. \\ La Jolla, CA 92037 USA
}

\section{D.H.L. Bishop \\ Natural Environment Research School \\ Institute of Virology \\ Mansfield Road \\ Oxford OX1 3SR, UK \\ G.P. Martelli \\ Instituto di Patologia Vegetale \\ Via Giovanni Amendola 165A \\ 70126 Bari \\ Italy}

\author{
S.A. Ghabrial \\ University of Kentucky \\ Dept. of Plant Pathology \\ S-305 Ag. Sc. Bl. N \\ Lexington, KY 40546 \\ USA
}
M.A. Mayo
Scottish Crop Research Institute
Invergowrie
Dundee DD2 5DA
UK

\author{
A.W. Jarvis \\ New Zealand Dairy Research \\ Institute \\ Private Bag \\ Palmerston North \\ New Zealand \\ M.D. Summers \\ Texas A \& M University \\ Dept. of Entomology \\ College Station, TX 77843-2475 \\ USA
}

\section{Contributors}

$\begin{array}{lll}\text { Ackermann, H.-W. } & \text { Brinton, M.A. } & \text { Gust, I.D. } \\ \text { Adam, G. } & \text { Brown, F } & \text { Hamilton, R.I. } \\ \text { Adrian, T. } & \text { Bruenn, J. } & \text { Hammond, J. } \\ \text { Alexander, D.J. } & \text { Brunt, A.A. } & \text { Hanzlik, T. } \\ \text { Atabekov, J.G. } & \text { Buchmeier, M.J. } & \text { Heinz, F.X. } \\ \text { Baldwin, M. } & \text { Buck, K.W } & \text { Hendry, D. } \\ \text { Bamford, D.H. } & \text { Burrell, C.J. } & \text { Herrmann, J.E. } \\ \text { Barbanti-Brodano, G. } & \text { Calisher, C.H. } & \text { Hierholzer, J.C. } \\ \text { Barnett, O.W. } & \text { Candresse, T. } & \text { Hill, J.H. } \\ \text { Bartha, A. } & \text { Carter, M.J. } & \text { Hillman, B.I. } \\ \text { Baxby, D. } & \text { Cavanagh, D. } & \text { Hinuma, Y } \\ \text { Beaty, B.J. } & \text { Chiba, S. } & \text { Hoey, E. } \\ \text { Beckage, N.E. } & \text { Clegg, J.C.S. } & \text { Holmes, K.V } \\ \text { Bergoin, M. } & \text { Coffin, J.M. } & \text { Horzinek, M.C. } \\ \text { Berns, K.I. } & \text { Collett, M. } & \text { Hoshino, Y. } \\ \text { Berthiaume, L. } & \text { Collinge, J. } & \text { Howard, C. } \\ \text { Billeter, M.A. } & \text { Collins, P.L. } & \text { Howley, P.M. } \\ \text { Bishop, D.H.L. } & \text { Dalrymple, J.M. } & \text { Hull, R. } \\ \text { Black, D.N. } & \text { Ghabrial, S. } & \text { Hunter, E. } \\ \text { Blissard, G.W. } & \text { Gibbs, M.J. } & \text { Incardona, N.L. } \\ \text { Bloom, M. } & \text { Gingery, R.E. } & \text { Jackson, A.O. } \\ \text { Boccardo, G. } & \text { Ginsberg, H. } & \text { Jaenisch, R. } \\ \text { Bozarth, R. } & \text { Goldbach, R. } & \text { Jahrling, P.B. } \\ \text { Bradley D } & \text { Goorha, R. } & \text { Johnson, J. } \\ \text { Brain, D.A. } & \text { Graf, T.M. } & \text { Joklik, W.K. } \\ \text { Briddon, R.W. } & \text { Granados, R.R. } & \text { Jordan, R. } \\ & & \end{array}$


Kaper, J.M.

Karabatsos, N.

Kashiwazaki, S.

Keddie, B.A.

Keese, $P$.

Lee, H.W.

Meshi, T.

Milne, R.G.

Minor, P.D.

Minson, A.C.

Monroe, S.S.

Morales, F.

Moss, B.

Moyer, R.W.

Muller, $\mathrm{H}$.

Murant, A.F.

Muzyczka, N.

Nagai, $Y$.

Nakamura, K.

Namba, S.

Nasz, I.

Neurath, A.R.

Newbold, J.

Nichol, S.T.

Nicholson, B.L.

Noordaa, J.V.

Nuss, D.L.

Nusse, R.

Nuttall, P.A.

Ohki, S.T.

Olszewski, N.E.

Oroszlan, S.

Orth, G.

Örvell, C.

Palese, $P$.

Palmenberg, A.

Patterson, J.

Payment, P.

Peters, C.J.

Peters, D.

Petterson, R.F.

Pickup, D.J.

Plagemann, P.G.W.

Possee, R.
Pringle, C.R.

Prusiner, S.B.

Purcifull, D.

Randles, J.W.

Rathjen, J.P.

Reavy, B.

Rice, C.M.

Rima, B.

Robinson, A.J.

Robinson, D.J.

Robinson, W.

Rock, D.

Roizman, B.

Romaine, C.P.

Rott, R.

Rueckert, R.

Russell, W.C.

Russo, M.

Rybicki, E.P.

Saif, L.

Samal, K.S.K.

Sanchez, A.

Schaffer, F.

Schaller, $\mathrm{H}$.

Schleper, C

Schlesinger, R.W.

Schmaljohn, C.S.

Scotti, P.D.

Shah, K.V.

Shikata, E.

Shope, R.E.

Shukla, D.D.

Siddell, S.G.

Siegl, G.

Smith, A.

Smith, J.S.

Southern, P.J.

Spaan, W.J.M.

Stanway, G.

Stoltz, D.B.

Strauss, J.H.

Stuart, K.

Studdert, M.J.

Summers, M.D.
Svoboda, J.

Swanepoel, R.

Taguchi, F.

Tal, J.

Talbot, P.J.

Tateishi, J.

Tattersall, P.

Taylor, J.M.

Teich, N.

ter Meulen, V.

Theilmann, D.A.

Thiel, H.J.

Tiollais, P.

Tischer, I.

Tomaru, K.

Toriyama, S.

Toyoshima, K.

Tripathy, D.N.

Turnbull-Ross, A.D.

Uyeda, I.

Van Alfen, N.K.

Van Duin, J.

Van Etten, J.L.

Van Regenmortel, M.H.V.

Varmus, $\mathrm{H}$.

Vinuela, E.

Volkman, L.E.

Wadell, G.

Walker, P.J.

Wang, A.

Wang, C.

Webb, B.A.

Weissmann, C.

Wen, Y-M.

Wengler, G.

Wickner, R.

Will, $\mathrm{H}$.

Wimmer, E.

Winton, J.R.

Wunner, W.H.

Yamashita, S.

Yin-Murphy, $\mathrm{M}$.

Zillig, W.

zur Hausen, $\mathrm{H}$. 


\section{CONTENTS}

Part I: INTRoduction to the Universal System of Virus Taxonomy

The History of Virus Taxonomy

The International Committee on Taxonomy of Viruses (ICTV) 1

The Universal System of Virus Taxonomy $\quad 2$

Virus Nomenclature 3

Structural, Genomic, Physicochemical and Replicative Properties of Viruses Used in Taxonomy 4

Some Properties of Viruses Used in Taxonomy

$\begin{array}{lr}\text { Taxonomy and Unambiguous Virus Identification } & 7\end{array}$

$\begin{array}{lr}\text { Taxonomy and the Adequate Description of New Viruses } & 7\end{array}$

Taxonomy in Diagnostic Virology $\quad 8$

$\begin{array}{lr}\text { The Future of Virus Taxonomy } & 8\end{array}$

Part II: The Viruses 15

Glossary of Abbreviations and Virological Terms $\quad 16$

$\begin{array}{ll}\text { Virus Diagrams } & 18\end{array}$

Taxa Listed Alphabetically $\quad 24$

$\begin{array}{lr}\text { Taxa Listed by Host } & 26\end{array}$

$\begin{array}{lr}\text { Taxa Listed by Nucleic Acid } & 28\end{array}$

$\begin{array}{ll}\text { Key to the Placement of Viruses in Taxa } & 30\end{array}$

The Order of Presentation of the Viruses $\quad 39$

$\begin{array}{lr}\text { Descriptions of Taxa } & 49\end{array}$

Part III: The International Committee on Taxonomy of Viruses 509

Officers and Members of the ICTV, 1990-1993 510

The Statutes of the ICTV, $1993 \quad 522$

The Rules of Virus Classification and Nomenclature, $1993 \quad 526$

The Format for Submission of New Taxonomic Proposals $\quad 528$

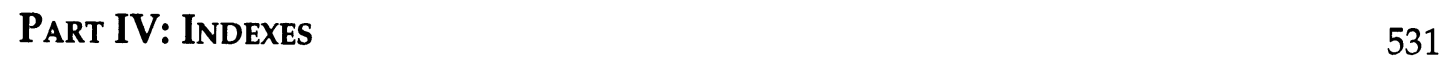

$\begin{array}{ll}\text { Author Index } & 533\end{array}$

$\begin{array}{ll}\text { Virus Index } & 551\end{array}$

$\begin{array}{ll}\text { Taxonomic Index } & 585\end{array}$ 